\title{
BECN1 wt Allele
}

National Cancer Institute

\section{Source}

National Cancer Institute. BECN1 wt Allele. NCI Thesaurus. Code C94670.

Human BECN1 wild-type allele is located in the vicinity of $17 q 21$ and is approximately 14 $\mathrm{kb}$ in length. This allele, which encodes beclin-1 protein, plays a role in both the regulation of both autophagy and apoptosis and the mediation of the host defense against viral infection. The gene may have tumor suppressor activity. 